\title{
Structure and Morphology Properties of Nanoparticle Hematite Pigment from Lathe Waste
}

\author{
Lilik Miftahul Khoiroh ${ }^{1}$, Asmaul Dwi Ayu Sholekah ${ }^{1}$, Eny Yulianti ${ }^{1}$ \\ ${ }^{1}$ Chemistry Department, UIN Maulana Malik Ibrahim Malang, Indonesia \\ Correspondence: Lilik Miftahul Khoiroh, Chemistry Department, UIN Maulana Malik Ibrahim Malang, Indonesia, Tel: \\ 6281555943366 E-mail: lilikmfx@kim.uin-malang.ac.id
}

\author{
Received: October 8, 2020 Accepted: February 18, 2021 Online Published: March 25, 2021 \\ doi:10.5539/ijc.v13n1p21 URL: https://doi.org/10.5539/ijc.v13n1p21
}

\begin{abstract}
Hematite coated PEG was synthesized by the sonication-calcination method. A variation of $\mathrm{Na}_{2} \mathrm{CO}_{3}$ is investigated to know the effect on structure and morphology. Characterization of samples are using X-ray fluorescence, X-ray diffraction, Scanning electron microscopy, and color reader techniques. XRF data showed that iron is the highest element in the precursor. The X-ray diffraction data confirm that $\mathrm{Fe}(\mathrm{OH})_{3}, \alpha-\mathrm{FeOOH}$, and $\mathrm{Fe}_{3} \mathrm{O}_{4}$ established at the sonication stage are then transformed into the $\alpha-\mathrm{Fe}_{2} \mathrm{O}_{3}$ phase after calcination. The X-ray diffraction data also was found that $\alpha-\mathrm{Fe}_{2} \mathrm{O}_{3}$ at $0.5 \mathrm{M}$ formed with the highest crystallinity degree. The scanning electron microscopy showed that the particle's shape is spherical, bar-shaped, and aggregate. However, the distribution of particles is not uniform and still displays agglomeration. The Color reader shows the highest degree of lightness obtained is at $1 \mathrm{M}$ variation.
\end{abstract}

Keywords: nanoparticle, $\alpha-\mathrm{Fe}_{2} \mathrm{O}_{3}$, lathe waste, $\mathrm{Na}_{2} \mathrm{CO}_{3}$, sonication

\section{Introduction}

\subsection{Introduce the Problem}

Nanoparticle hematite has attracted more attention and more developed in recent years for functional color properties. R. M. Cornell and U. Schwertmann (2003) explained that structure, size, and shape of particles could affect the color of hematite. Bilalodin et al. (2015) on the research explained that iron oxide of $926.4 \mathrm{~nm}$ particle size colored black, iron oxide of $72.2 \mathrm{~nm}$ particle size colored red, and iron oxide of $349 \mathrm{~nm}$ particle size colored yellow. Each iron oxide compound has different morphology distinguishable from one another. Based on Wei Wang et al's research (2008), the morphology of Iron oxide $\beta-\mathrm{FeOOH}$ is spherical with an amorphous structure and stacked as cubic hematite.

The synthesis of nanoparticle hematite pigment is influenced by several factors, including synthesis method, precursor type, and concentration of the precipitating agent. These factors will affect crystallinity, particle size, shape, and distribution of particles characterized by the differences in hematite color (Pramanik et al., 2005). Synthesis of iron oxide nanoparticle hematite has been carried out using several methods, including the precipitation-calcination route (Aji et al., 2007; Khoiroh, 2019), hydrothermal (He et al., 2016; Khalil et al., 2014), sol-gel (Dar et al. 2007), and ultrasonic sonochemistry (Hassanjani-Roshan et al., 2011). The sonication method is the easiest and most effective method for large-scale production with precise size control, high morphology, and crystallinity (Khalil et al., 2017). According to Firnando (2015), it was proven that ultrasonic waves in the sonication method can separate aggregation and that the effect of sonication (ultrasonic) can produce a product of nanocrystal size. According to Khalil et al. (2017), using ultrasonic sonochemical methods has successfully produced monodispersed hematite nanoparticles with a uniform shape and particle size of about $14 \mathrm{~nm}$.

Lathe waste contains high iron, which can potentially be used to produce hematite. Hematite can be synthesized from pure compounds or high-iron containing waste. Based on Sobirin et al., (2015) research, hematite synthesized from waste steel (mill scale) yielding product of orthorhombic structures. Therefore, it is counted to reduce pollution by processing lathe waste into hematite pigment (Khoiroh et al., 2019) (Dražić et al., 2017). Based on Blanco-Andujar et al., (2012) research, sodium carbonate is a suitable precipitating agent to be used at the synthesis of nanoparticle hematite. The average particle size obtained was about $10 \mathrm{~nm}$, and the shape of the particles was cubic and uniform.

In this study, hematite was synthesized from lathe waste through the sonication-calcination method and coated with polymer just as polyethylene glycol (PEG) as a stabilizer. An attempt has been made to understand the effect of the concentration of precipitating agent $\mathrm{Na}_{2} \mathrm{CO}_{3}$ on nanoparticle formation. The precursor was characterized by XRF to 
know the content of the metal. The products were well characterized by various characterization techniques such as X-Ray Diffraction (XRD), Scanning Electron Microscopy (SEM), and color reader.

\section{Materials and Methods}

\subsection{Ferric $\left(\mathrm{Fe}^{3+}\right)$ Precursors Preparation}

The ferric precursor $\left(\mathrm{Fe}^{3+}\right)$ was prepared by mixing $30 \mathrm{gr}$ iron samples with $500 \mathrm{~mL}$ diluted nitric acid for 24 hours, then heated until forming a slurry. The presence of ferric ion was determined by qualitative test; the sample was dripped with $\mathrm{NaOH} 0.1 \mathrm{M}$, which carried out the red sediment that shown ferric ion.
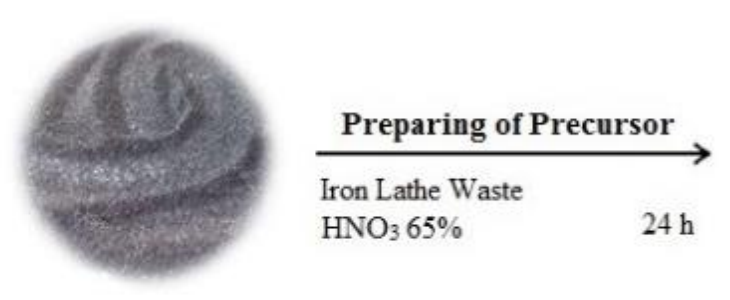

Iron Lathe Waste $\mathrm{HNO}_{3} 65 \%$
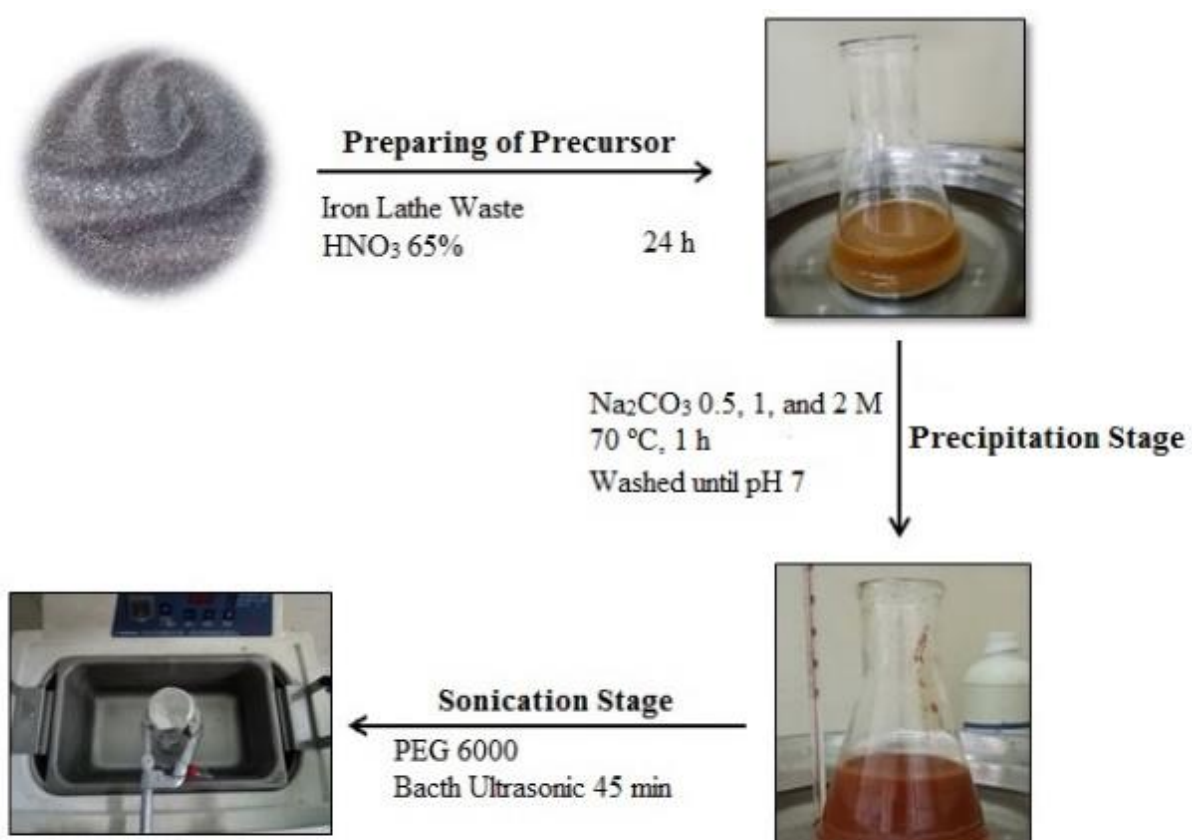

$\leftarrow \quad$ Sonication Stage

PEG 6000

Bacth Ultrasonic $45 \mathrm{~min}$
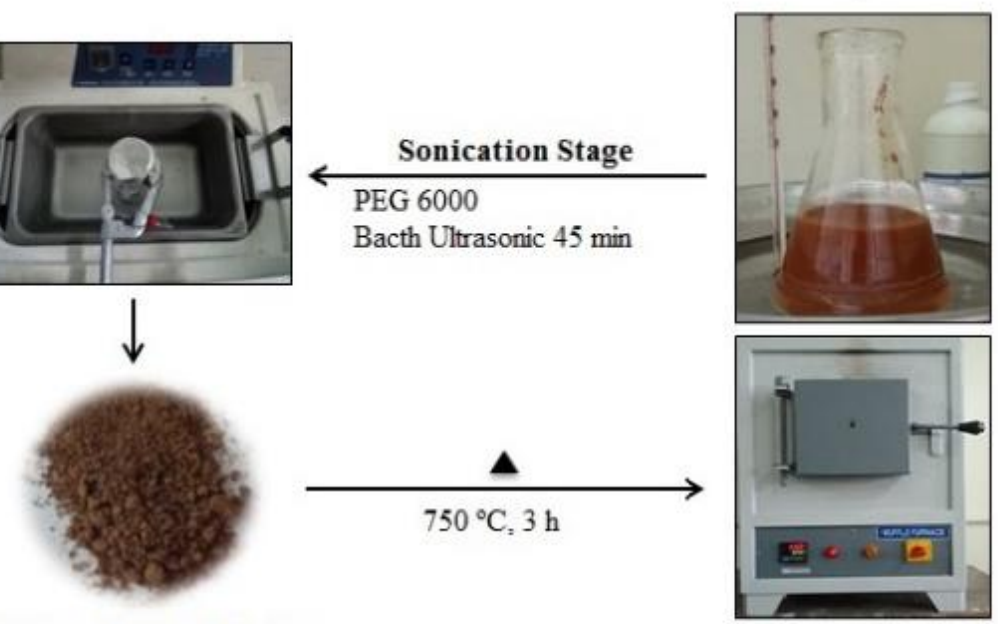

$\mathrm{Fe}(\mathrm{OH})_{3}, a-\mathrm{FeOOH}, \mathrm{Fe}_{3} \mathrm{O}_{4}$

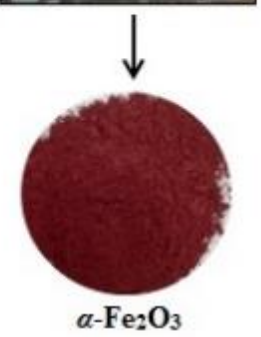

Figure 1. Synthesis of hematite through sonication method

\subsection{Synthesis of Hematite Pigment}

Ferric precursor was dissolved into $250 \mathrm{~mL}$ distilled water and then added with precipitating agent $\mathrm{Na}_{2} \mathrm{CO}_{3}$ of various concentrations; $0.5 ; 1 ; 2 \mathrm{M}$. The $\mathrm{pH}$ of the mixture was regulated to remain at 6 then the sample was heated at $70^{\circ} \mathrm{C}$ for 1 hour. The solution was cooled at room temperature then decanted. After that, it was filtered and washed with distilled water to $\mathrm{pH} 7$ and dried at room temperature. Brownness solid was formed from this step, then calcined at $750^{\circ} \mathrm{C}$ as Figure 1 . The iron oxide $\alpha-\mathrm{Fe}_{2} \mathrm{O}_{3}$ nanoparticles are produced by the following solid-state reaction: 


$$
\begin{aligned}
2 \mathrm{Fe}\left(\mathrm{NO}_{3}\right)_{3(a q)}+4 \mathrm{H}_{2} \mathrm{O}(l) & 3 \mathrm{Na}_{2} \mathrm{CO}_{3(a q)} \rightarrow 2 \mathrm{Fe}(\mathrm{OH})_{3(s)}+6 \mathrm{NaNO}_{3(a q)}+\mathrm{H}_{2} \mathrm{O}_{(l)}+3 \mathrm{CO}_{2(g)} \\
& \mathrm{Fe}(\mathrm{OH})_{3(s)} \rightarrow \mathrm{FeOOH}_{(s)}+\mathrm{H}_{2} \mathrm{O}(l) \\
& 2 \mathrm{FeOOH}{ }_{(s)} \rightarrow \alpha-\mathrm{Fe}_{2} \mathrm{O}_{3(s)}+\mathrm{H}_{2} \mathrm{O}_{(g)}
\end{aligned}
$$

\subsection{Characterizations}

The composition of the precursor was characterized using X-R Fluorosense analysis. The crystalline structure and crystallite size were examined with X-ray diffraction (XRD) analysis using a Cu Ka $(1,5418 \AA)$ source $(40 \mathrm{kV}, 40 \mathrm{~mA})$ from Philip X-Pert. The crystallite size was determined with the Debye Scherer formula. The synthesized hematite morphology was evaluated through a scanning electron microscope (SEM, FEI type Inspect-S50). Color characteristics were analyzed using a white Xenon lamp with D65 illuminate from Minolta CR-10. The value of C* and $\mathrm{H}^{\mathrm{o}}$ was calculated with the following formula (Cornell and Schwertmann. 2000):

$$
\begin{gathered}
\mathrm{C}^{*}=\left[\left(\mathrm{a}^{*}\right)^{2}+\left(\mathrm{b}^{*}\right)^{2}\right]^{1 / 2} \\
\mathrm{H}^{\mathrm{o}}=\tan ^{-1}\left(\mathrm{~b}^{*} / \mathrm{a}^{*}\right), \text { degree } 0^{\circ} \leq \mathrm{H}^{\mathrm{o}} \leq 360^{\circ}
\end{gathered}
$$

\section{Results and Discussion}

\subsection{Characterization with XRF}

The chemical composition of the precursor of the manufactured from lathe waste is shown in Table 1, which shows that iron element was found in form $\mathrm{Fe}_{2} \mathrm{O}_{3}$ as the highest content by $96.3 \%$, which means that $\mathrm{Fe}_{2} \mathrm{O}_{3}$ is the primary oxide in the precursor. The presence of oxide and another element because of the precursor is made from lathe waste, which contains another element in its preparation, although not exceed $0.9 \%$. The high content of iron shown that the lathe waste is the potential to synthesize to be hematite.

Table 1. XRF result of the ferric precursor of iron oxide

\begin{tabular}{cc}
\hline Component & \% Content \\
\hline $\mathrm{Fe}_{2} \mathrm{O}_{3}$ & 96.3 \\
$\mathrm{Eu}_{2} \mathrm{O}_{3}$ & 0.81 \\
$\mathrm{MnO}$ & 0.47 \\
$\mathrm{Br}$ & 0.35 \\
$\mathrm{SiO}_{2}$ & 0.81 \\
$\mathrm{OsO}_{4}$ & 0.24 \\
$\mathrm{Cr}_{2} \mathrm{O}_{3}$ & 0.27 \\
$\mathrm{CuO}$ & 0.19 \\
$\mathrm{P}_{2} \mathrm{O}_{5}$ & 0.38 \\
$\mathrm{CaO}^{2}$ & 0.13 \\
$\mathrm{La}_{2} \mathrm{O}_{3}$ & 0.06 \\
\hline
\end{tabular}




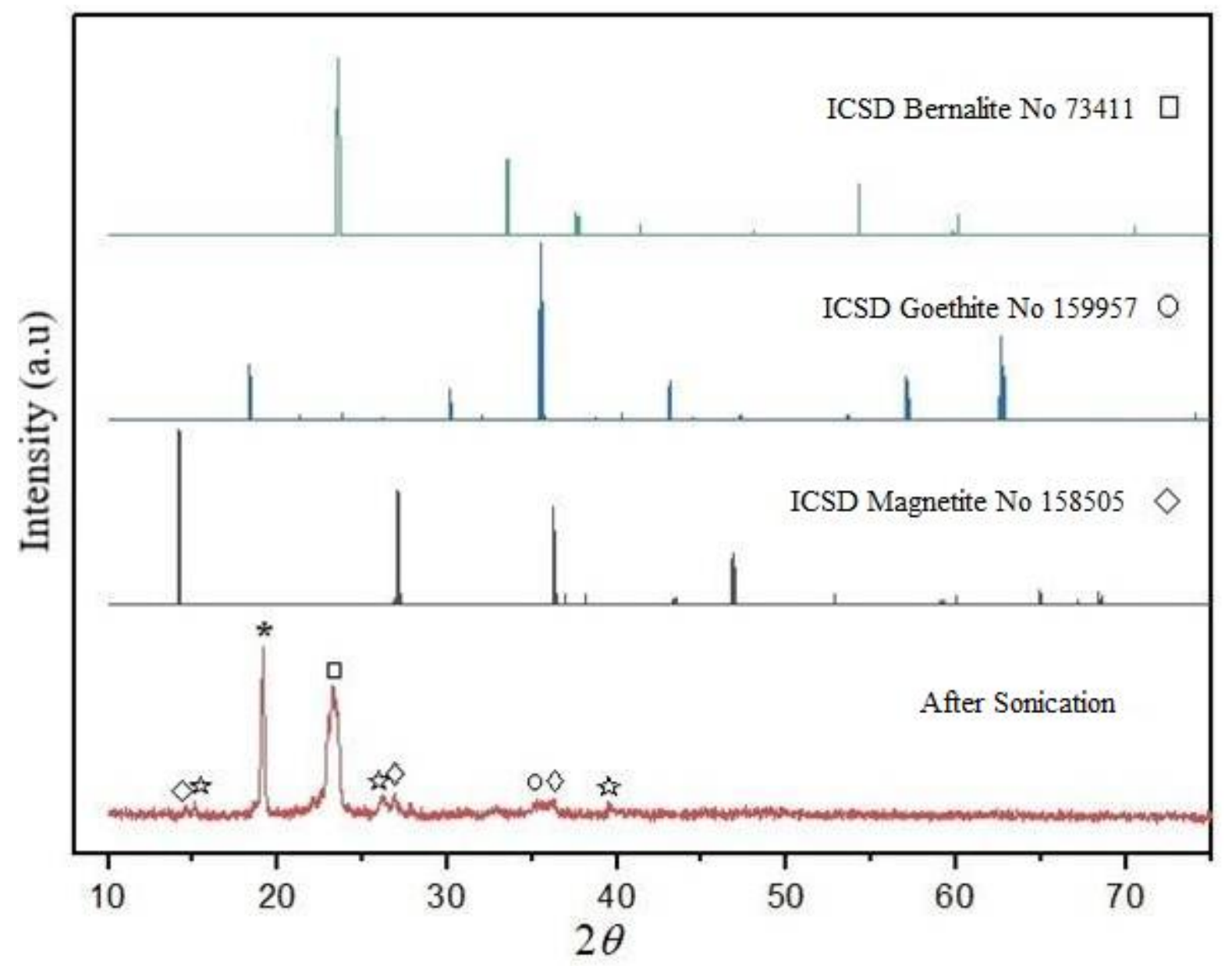

Figure 2. X-ray diffraction pattern of the sample after sonication

\subsection{Characterization with X-ray Diffraction}

The X-ray diffraction pattern of the sample $(0.5 \mathrm{M})$ after sonication showed in Figure 2 displayed many phases in the sample, which is bernalite, goethite, and magnetite phase is formed. The characteristic of the bernalite phase is indicated by the presence of peaks at $2 \theta\left(^{\circ}\right) 23.2573$ according to ICSD No. 73411, goethite $(\alpha-\mathrm{FeOOH})$ at $2 \theta\left(^{\circ}\right) 14.6080$; 26.8934; dan 36.2991 according to ICSD No. 159957 and magnetite $\left(\mathrm{Fe}_{3} \mathrm{O}_{4}\right)$ at $2 \theta\left(^{\circ}\right) 35.2904$ according to ICSD No. 158505 whereas the sharp peak at $2 \theta\left(^{\circ}\right) 19,1420$ revealed the presence of polyethylene glycol (PEG) (Tu et al., 2019). PEG content on the surface of iron oxide is due to the addition of PEG during sonication, which aims to stabilize it so that the particles formed are uniform in size even though they are given ultrasonic energy. 


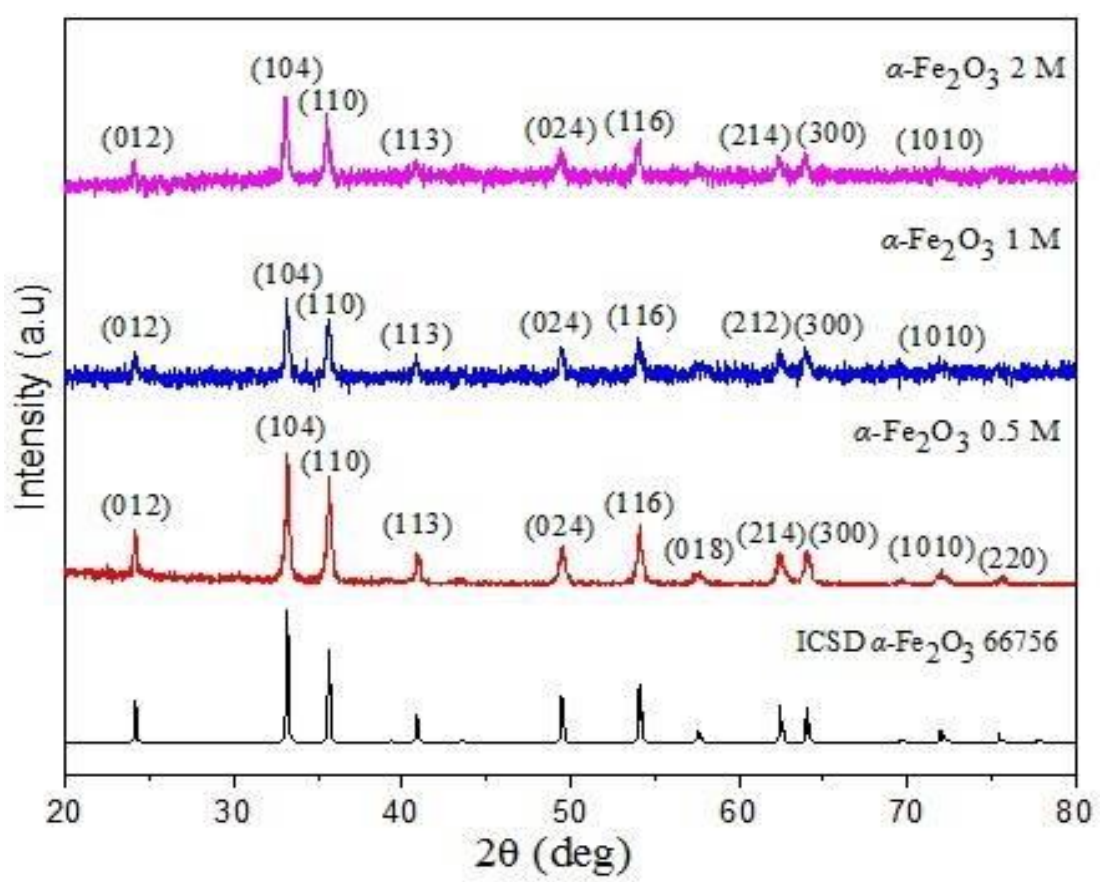

Figure 3. X-ray diffraction pattern of hematite

The transformation of bernalite, gothite, and magnetite to hematite phase is displayed in the X-ray diffraction pattern in Figure 3. The peaks observed at $2 \theta(24.16,33.18,35.64,41.00,49.48,54.08) \AA$ correspond to those of hexagonal of hematite with hkl (012) (104) (110) (113) (024) (116) (018) (214) (300) (1010) (220) according to ICSD 66756, with a space group of R3 ${ }^{-}$. During calcination, high temperature and energy can transform bernalite, gothite, and magnetite into pure hematite phases, shown in the absence of another peak beside the hematite peak and high crystallinity indicated by sharp peaks. The highest crystallinity degree of hematite is achieved at hematite $0.5 \mathrm{M}$ of $\mathrm{Na}_{2} \mathrm{CO}_{3}$, which is indicated all of the peaks of diffraction are sharper than others. The $\mathrm{Na}_{2} \mathrm{CO}_{3}$ precipitating agent's effect on the diffraction pattern of hematite can be possible due to the presence of anionics such as carbonate ions during the synthesis process. The carbonate ion in $\mathrm{Na}_{2} \mathrm{CO}_{3}$ tends to precipitate in the form of molecules such as amorphous of $\mathrm{Fe}_{2}(\mathrm{OH})_{2} \mathrm{CO}_{3}$ or $\mathrm{Fe}(\mathrm{OH})_{3}$ phase (Tangale et al., 2013).

The diffraction pattern was obtained by varying the concentration of precipitation agent at the synthesis after calcination and concluded that the peak intensity between one concentration and the other is different, as displayed in Figure 4. Based on Figure 4, the $2 \theta$ positions for $1 \mathrm{M}$ and $2 \mathrm{M}$ hematite have shifted toward the smaller $2 \theta$; this indicates that the sample has a larger crystal size. A position shift of $2 \theta$ allows changes in lattice parameters (Kumar et al., 2015). Data obtained also indicates that peak intensity gets higher as the $\mathrm{Na}_{2} \mathrm{CO}_{3}$ concentration smaller.

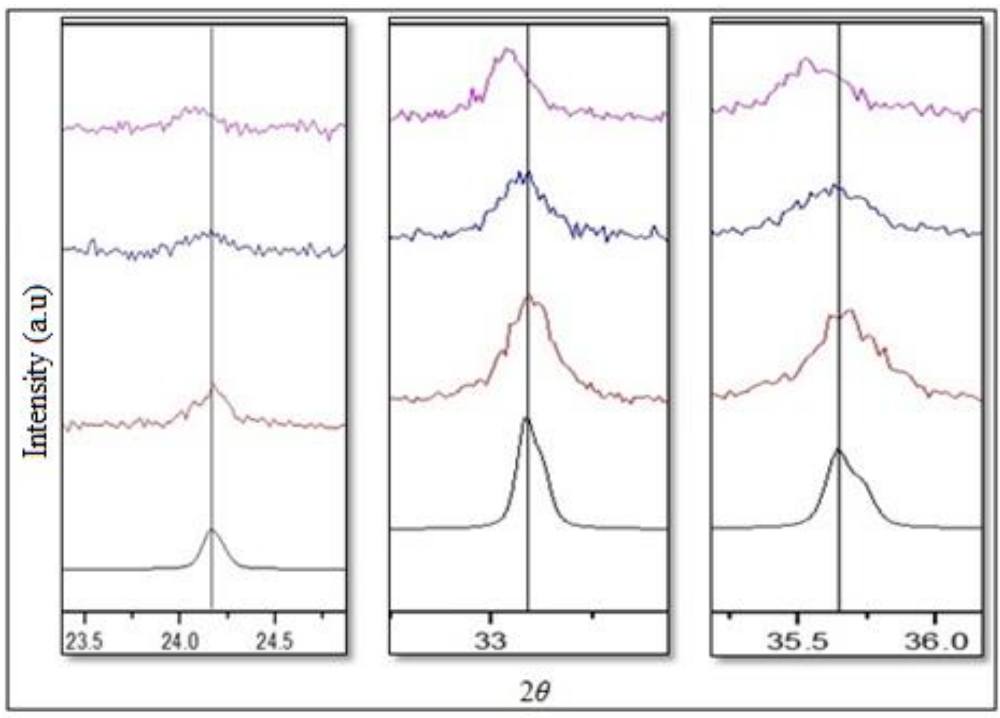

Figure 4. $2 \theta$ shift of synthesized hematite 
Table 2. Crystallite size of hematite

\begin{tabular}{ccc}
\hline Hematite & $2 \theta$ & The crystallite size $(\mathrm{nm})$ \\
\hline $0.5 \mathrm{M}$ & 33.1936 & 46.29 \\
& 35.6575 & 59.89 \\
& 54.1232 & 32.02 \\
\hline $1 \mathrm{M}$ & 33.1522 & 40.85 \\
& 35.6193 & 30.84 \\
& 54.0656 & 65.92 \\
\hline $2 \mathrm{M}$ & 33.0886 & 54.42 \\
& 35.5127 & 35.22 \\
& 54.1115 & 52.73 \\
\hline
\end{tabular}

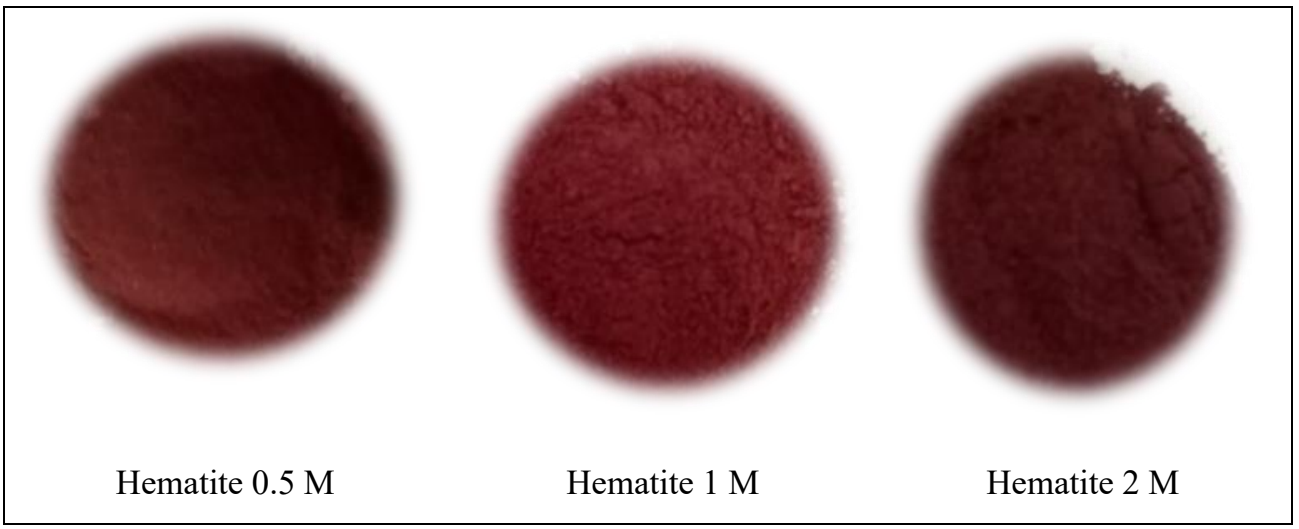

Figure 5. The visual color of hematite synthesized

The crystallite size of various samples is listed in Table 2. Crystallite size is calculated with The Debye Scherrer equation using broadening of the most intense peaks from the X-ray diffraction pattern of hematite. The smallest crystallite size of hematite synthesized is achieved at $1 \mathrm{M}$. Crystallite size can affect sample color. The smallest crystallite size exudes the lightest pigment color, as displayed in Figure 5. The visual color of hematite pigment shows that at $1 \mathrm{M}$ variation, the pigment exhibits the lightest color. The pigment's color grows brighter as the crystal size becomes smaller (Sobirin et al., 2015).

\subsection{Characterization Through Scanning Electron Microscope}

SEM analysis result of hematite $0.5 \mathrm{M}$ variation with 50.000 times magnification shows that particle shape distribution is relatively uniform, but agglomeration still occurs. The particle size of hematite $0.5 \mathrm{M}$ variation is around $38.33 \mathrm{~nm}$. The particle's shape at a magnification of 50,000 times is spherical, as seen in the SEM results in Figure 6. At $1 \mathrm{M}$ variation, the synthesized hematite is bar-shaped with surface morphology seems uniform; however, aggregation still occurs with the particle size obtained is around $37.99 \mathrm{~nm}$. Meanwhile, the $2 \mathrm{M}$ variation's product after 50,000 magnification showed particles taking the shape of aggregate and not uniformly distributed with a particle size around $43.03 \mathrm{~nm}$. 

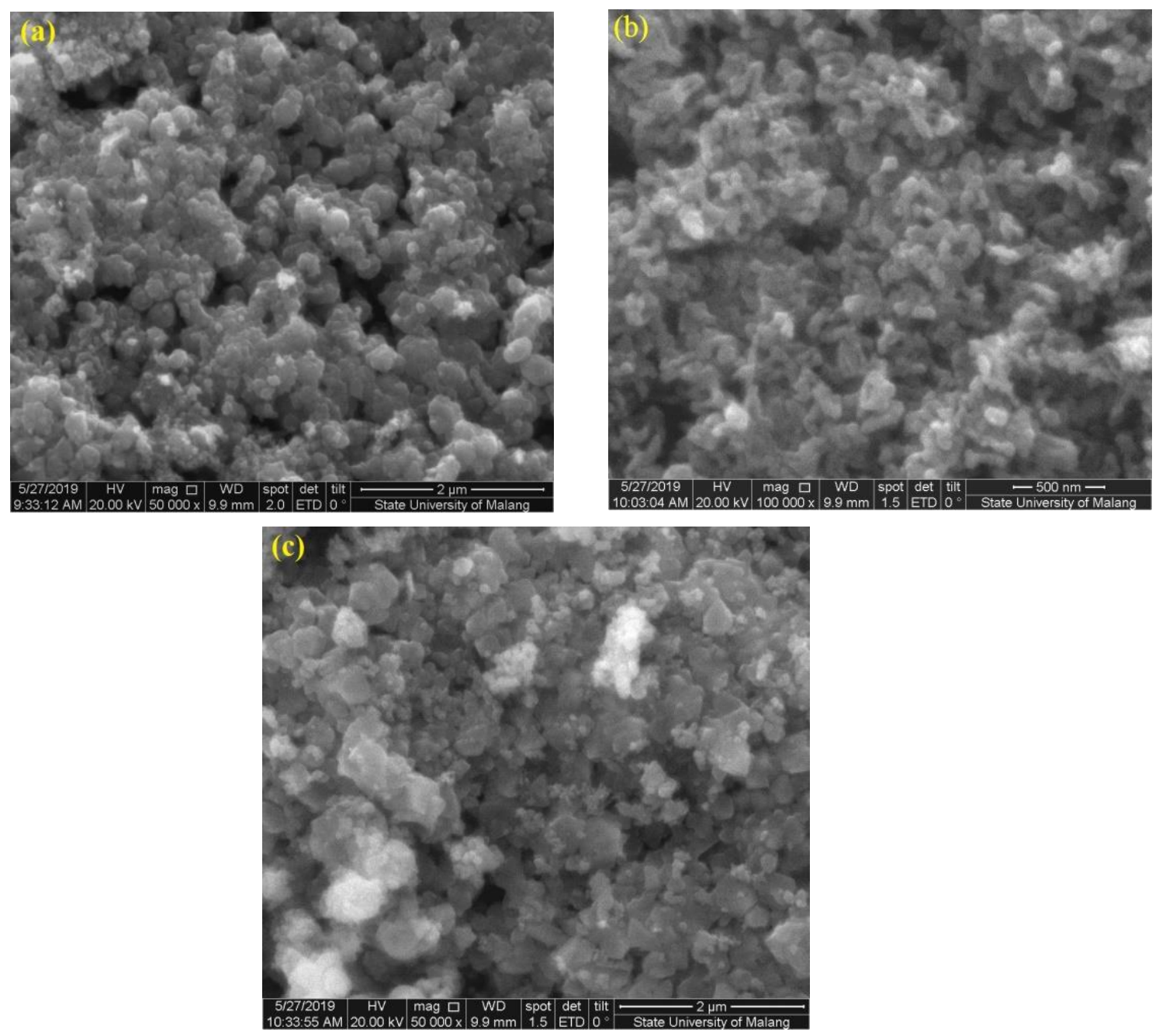

Figure 6. SEM images of hematite obtained through different concentration of precipitation agent $\mathrm{Na}_{2} \mathrm{CO}_{3}$ a) $0.5 \mathrm{M}$ b) 1 $\mathrm{M} \mathrm{c)} 1.5 \mathrm{M}$

\subsection{Characterization with Color Reader}

Based on Table 3, the lightness degree of all concentration variation's product matches that of the standard with the highest lightness degree obtained at $1 \mathrm{M} \mathrm{Na}_{2} \mathrm{CO}_{3}$, which is possible as $1 \mathrm{M}$ variation's product has the smallest crystal size. The values of $\mathrm{a}^{*}$ and $\mathrm{b}^{*}$ of the three concentration variation are positive; this indicates that the sample is dominantly red and yellow. The red color appeared is due to the presence of red iron oxide or hematite- the presence of peaks following those of hematite in the XRD results. Hematite with $1 \mathrm{M} \mathrm{Na}_{2} \mathrm{CO}_{3}$ exhibits the highest a* value; it is attributed to the degree of lightness and color purity of the product, which is higher than those of $0.5 \mathrm{M}$ and $2 \mathrm{M}$ variation. 
Table 3. Optical data of hematite synthesized

\begin{tabular}{cccc}
\hline Color system & Hematite $0.5 \mathrm{M}$ & Hematite 1 M & Hematite 2 M \\
\hline$L^{* 1}$ & 33.8 & 35.1 & 33.7 \\
$C^{* 2}$ & 21.439 & 26.792 & 23.284 \\
$H^{\circ 3}$ & 33.385 & 34.059 & 35.716 \\
$a^{* 4}$ & 17.9 & 22.2 & 18.9 \\
$b^{* 5}$ & 11.8 & 15.0 & 13.6
\end{tabular}

The value of $\mathrm{H}^{\circ}$ (color pattern) increases with the increasing of precipitating agent concentration. The hue value of the synthesized pigment is closer to the red spectrum due to hematite presence. It is evident from the peaks of the diffraction pattern appears at $2 \theta$ (33.1). The chroma of the synthesized pigment is also directly proportional to its particle size, indicating that as the particle size gets smaller, it exudes a higher level of lightness and purity (Buxbaum, 2005). The higher the crystallinity level, the brighter the hematite color and the higher the color values have the smaller particle size. Based on the data of $\mathrm{L}^{*}, \mathrm{C}^{*}, \mathrm{H}^{*}, \mathrm{a}^{*}$, and $\mathrm{b}$, the best color value is obtained at $1 \mathrm{M}$ variation.

\section{Conclusion}

Nanoparticle hematite coated PEG was synthesized from lathe waste that contains 97\% of iron using the sonication method has a hexagonal structure with space group $\mathrm{R}-3 \mathrm{C}$. The highest crystallinity of hematite was obtained at $0.5 \mathrm{M}$ but the highest lightness of color and degree of redness obtained at $1 \mathrm{M}$. The morphology of hematite was like spherical, bar-shaped uniform and aggregates. The highest lightness of color and degree of redness obtained at $1 \mathrm{M}$.

\section{References}

Aji, M. P., Yulianto, A., \& Satria, B. (2007). Sintesis Nano Partikel Magnetit, Maghemit Dan Hematit Dari Bahan Lokal. Jurnal Sains Materi Indonesia Indonesian Journal of Materials Science, 536, 106-108.

Bilalodin, Irayani, Z., Sehah, \& Sugito. (2015). Sintesis Dan Karakterisasi Pigmen Warna Hitam Merah Dan Kuning Berbahan Dasar Pasir Besi. Jurnal Fisika Universitas Jenderal Sudirman, 10(2). https://doi.org/10.20884/1.jm.2015.10.2.5

Blanco-Andujar, C., Daniel, O., Quentin, A., Pankhurst, \& Nguyen, T. K. T. (2012). Elucidating the Morphological and Structural Evolution of Iron Oxide Nanoparticles Formed by Sodium Carbonate in Aqueous Medium. Journal of Materials Chemistry, 22(25), 12498. https://doi.org/10.1039/c2jm31295f

Buxbaum, G., \& Pfaff, G. (2005). Indutsrial Inorganic Pigment, The 3rd Edition. Weinheim: Wiley-VCH. https://doi.org/10.1002/3527603735

Cornell, R. M., \& Udo, S. (2000). Iron Oxides in the Laboratory Preparation and Characterization, Wiley VCH.

Cornell, R. M., \& Udo, S. (2003). The iron oxides: structure, properties, reactions, occurrences, and uses. 2nd, completely rev. and extended ed. Weinheim: Wiley-VCH. https://doi.org/10.1002/3527602097

Dar, M. A., Ansari, S. G., Rizwan, W., Young, S. K., \& Hyung, S. S. (2007). The Synthesis of Maghemite and Hematite $\left(\gamma-\quad \mathrm{Fe}_{2} \mathrm{O}_{3}, \quad \alpha-\mathrm{Fe}_{2} \mathrm{O}_{3}\right) \quad$ Nanospheres. Materials $\quad$ Science $\quad$ Forum, $534, \quad 157-160$. https://doi.org/10.4028/www.scientific.net/MSF.534-536.157

Dražić, G., Štefanić, G., Jurkin, T., \& Gotić, M. (2017). Impact of cadmium and phosphate ions on the hematite nanorings formation. Journal of Molecular Structure, $1140, \quad 113-121$. https://doi.org/10.1016/j.molstruc.2016.12.089

Firnando, H. G. (2015). Pengaruh Suhu Pada Proses Sonikasi Terhadap Morfologi Partikel Dan Kristalinitas Nanopartikel. Jurnal Fisika Unand, 4(1), 5.

Hassanjani-Roshan, Amir, Mohammad, R. V., Ali, S., \& Zohreh, R. (2011). Synthesis of Iron Oxide Nanoparticles Via

\footnotetext{
1 Lightness of color

2 Chroma

${ }^{3}$ Hue

4 degree of redness

5 degree of yellowness
} 
Sonochemical Method and Their Characterization. Particuology, 9, 95-99. https://doi.org/10.1016/j.partic.2010.05.013

He, K., Bin, S., Lingtong, Z., Wangwei, L., Jin, L., Gaoling, Z., \& Gaorong, H. (2016). Size-Controlled Synthesis of Hematite Mesocrystals. The Royal Society of Chemistry, 18 (5), 754-758. https://doi.org/10.1039/C5CE00849B

Khalil, M., Jianjia, Y., Ning, L., \& Robert, L. L. (2014). Hydrothermal Synthesis, Characterization, and Growth Mechanism of Hematite Nanoparticles. Journal of Nanoparticle Research, 16(4), 2362. https://doi.org/10.1007/s11051-014-2362-x

Khoiroh, L. M., Al-Chabib, M. N., \& Prasetyo, A. (2019). Synthesis and characterization of hematite $\left(\alpha-\mathrm{Fe}_{2} \mathrm{O}_{3}\right)$ from lathe waste using co-precipitation -calcination method. IOP Conference Series: Materials Science and Engineering, 578, 012004. https://doi.org/10.1088/1757-899X/578/1/012004

Kumar, D., Singh, H., Jouen, S., Hannoyer, B., \& Banerjee, S. (2015). Effect of precursor on the formation of different phases of iron oxide nanoparticles. RSC Advances, 5, 7138-7150. https://doi.org/10.1039/C4RA10241J

Pramanik, N. C., Tarequl, I. B., Makoto, N., Tatsuo, F., Jun, T., \& Sang, I. (2005). Synthesis and characterization of Cerium Substituted Hematite by Sol-gel Method. Materials Letters, 59, 3783-3787. https://doi.org/10.1016/j.matlet.2005.06.056

Sobirin, M., Margi, F., Rofiatul, Z., Yani, P., Fandi, M. A. S., \& Andya, S. P. P. (2015). Sintesis dan Karakterisasi Pigmen Nano Hematit dari Limbah Baja (mill scale) dengan Metode laux. Seminar Nasional Mahasiswa Fisika.

Tangale, N. P., Niphadkar, P. S., Deshpande, S. S., \& Joshi, P. N. (2013). Dehydrogenation of Cyclohexanol Over $\mathrm{Cu} / \mathrm{A} 12 \mathrm{O} 3$ Catalysts Prepared with Different Precipitating Agents. Applied Catalysis A: General, 467, 421-429. https://doi.org/10.1016/j.apcata.2013.07.063

Tu, J., Li, H., Zhang, J., Hu, D., Cai, Z., Yin, X., Dong, L., Huang, L., Xiong, C., \& Jiang, M., (2019). Latent Heat and Thermal Conductivity Enhancements in Polyethylene Glycol/Polyethylene Glycol-Grafted Graphene Oxide Composites. Advanced Composites and Hybrid Materials, 2, 471-480. https://doi.org/10.1007/s42114-019-00083-X

Wang, W., Jane, H., Wei, W., Jane, Y. H., \& Baohua, G. (2008). Structure and Morphology Evolution of Hematite $\left(\alpha-\mathrm{Fe}_{2} \mathrm{O}_{3}\right)$ Nanoparticles in Forced Hydrolysis of Ferric Chloride. Advanced Materials Research, 2-8. https://doi.org/10.1021/jp800683j

\section{Copyrights}

Copyright for this article is retained by the author(s), with first publication rights granted to the journal.

This is an open-access article distributed under the terms and conditions of the Creative Commons Attribution license (http://creativecommons.org/licenses/by/4.0/). 